\title{
PERSPEKTIF BARAKAH DALAM KESARJANAAN MUSLIM BARAT: STUDI ATAS PEMIKIRAN NAOUMAN ALI KHAN DI YOUTUBE
}

\author{
Lia Qurrota Aini \\ Universitas Nurul Jadid, Paiton Probolinggo \\ E-mail: liaqurrotaaini@gmail.com
}

\begin{abstract}
:
Barakah has been around for a long time even though it does not appear to be about its form, but everyone must feel the sweetness of Barakah. The problem is that Barakah has experienced a decline and has even begun to become extinct because its existence is not clearly visible. That is caused by the lack of public awareness of the power of Allah, so that it depends on the progress of science and technology at this time. Therefore, the author examines the interpretation of Nouman Ali Khan through Youtobe which contains a discussion of baraka as a form of recommendation to the public that the interpreter is very suitable to be studied at the present time. This article includes thematic methods (maudhu'i) as well as patterns of adab ijtima'i with a linguistic approach, so that the discussion presented by Nouman Ali Khan can be used as a basis for knowing, understanding and changing the paradigm of society through cognitive effects, affective effects, and behavioral effects.
\end{abstract}

Keyword: Barakah, Naouman Ali Khan, Metodologi.

\section{Pendahuluan}

Dahulu tafsir bisa digunakan dalam bentuk media cetak, yaitu berbagai kajian permasalahan dan penyelesaiannya dikutip dalam bentuk kitab oleh ulamaulama terkemuka. Kemudian, kajian tafsir lambat laun memanfaatkan fasilitas teknologi. Mulai dari kitab-kitab yang dicetak sudah bisa dikonsumsi melalui e-book serta penjelasan kemusykilan al-Qur'an yang dahulunya harus hadir di tempat musyawaroh sudah tidak dibutuhkan lagi pada zaman sekarang, hanya cukup search dan klik semua permasalahan sudah bisa terselesaikan secara instant. 
Tantangan bagi umat muslim adalah menyalurkan ajaran Islam yang terdapat dalam al-Qur'an kepada media sosial. Berbagai aplikasi yang digunakan, yakni facebook, instagram, twitter, whatsapp, telegram hingga youtobe. Semua itu merupakan metode baru untuk berdakwah. Oleh karena itu, seorang muslim harus bisa memfilter tentang kualitas pendakwah dalam menuangkan kajian ke-Islamannya sehingga layak diaplikasikan kepada kehidupan. ${ }^{1}$

Meningkatnya pengguna internet di dunia termasuk Indonesia, bisa dipastikan karena turunnya tiras media cetak. Aceng Abdullah mencatat dalam buku Komunikasi Kontekstual bahwa neraca penggunaan internet di Indonesia pada tahun 2009 berjumlah sekitar 40 juta orang. Amgka tersebut merupakan angka tertinggi di Asia Tenggara, tetai rasio jumlah penduduk tetap kalah kepada negara Singapura dan Malaysia. Sampai tahun 2010 diperkiraan pengguna jejaring sosial facebook sudah mencapai 500 juta orang. ${ }^{2}$

Pada tanggal 06 Maret 2019, We are Sosial melansir tentang infografik terkait pengguna media sosial di Indonesia mencapai 150 juta orang. Berbagai aplikasi yang digunakan, youtobe menduduki tingkat paling atas. ${ }^{3}$ Karena content youtobe dikemas menjadi video singkat yang dipublikasikan sehingga mempermudah masyarakat yang memiliki halangan untuk hadir, baik dalam keadaan macet, di tempat santai, di tempat kerja maupun di tempat tidur bisa menikmatinya. ${ }^{4}$

Salah satu cendikiawan muslim yang memanfaatkan teknologi sebagai sarana dakwahnya dalam bidang tafsir ialah Nouman Ali Khan. Seorang kelahiran Jerman yang berdomisili di Amerika Serikat. Nouman menyebarkan dakwah Islam melalui berbagai macam media, namun media pokoknya adalah youtobe. Hal yang demikian menjadi keunikan tersendiri bagi Nouman daripada mufassir yang lain. ${ }^{5}$ Karena mufassir lain menggunakan youtobe sebagai media pendukung.

Pada tahun 2019, Nouman termasuk salah satu muslim yang berpengaruh daripada 500 muslim lainnya. Nouman merupakan founder dan CEO dari situs youtube bayyinah.com yang telah mengajarkan sebanyak 10.000

\footnotetext{
${ }^{1}$ Nadirsyah Hosen, Tafsir al-Qur'an di Medsos, (Yogyakarta: Bentang Pustaka, 2019), v.

2 Engkus Kuswarno, Nina Winangsih Syam, dkk., Komunikasi Kontekstual, (Bandung: PT Remaja Rosdakarya, 2010), 467.

3 https://katadata.co.id/infografik/2019/03/06/YouTube-medsos-no-1-di-indonesia diakses pada tanggal 06 Maret 2019.

${ }^{4}$ Ibid., v.

${ }^{5}$ Moh. Azwar Hairul, "Tafsir al-Qur'an di Youtobe”, Al-Fanar: Jurnal Ilmu al-Qur'an dan Tafsir, 2 (28 Agustus, 2019), 91.
}

54 | Muṣhaf: Jurnal Tafsir Berwawasan Keindonesiaan Volume 1. Nomor 1, Desember 2020. 
orang lebih melalui seminar traveling serta mendapatkan followers sebanyak satu juta lebih pada sosial medianya. ${ }^{6}$

Salah satu videonya yang menarik diteliti menurut penulis ialah tentang Barakah .Barakah butuh dikaji pada bingkai zaman digital karena kemerosotan rasa hamba kepada sang Kuasa disebabkan kemajuan teknologi yang mendorongnya untuk lebih mempercayai sesuatu yang nyata daripada gaib, atau lebih memilih hal yang instant daripada berproses.

Belakangan ini, manusia terkecoh oleh perkembangan sains dan teknologi, karena kurang memperhatikan terhadap teosentrisme. Teosentrisme adalah paham yang menempatkan Allah sebagai pusat dan pangkal perilaku serta gerak hidup manusia. Allah adalah pusat serta pangkal segala sesuatu dalam kehidupan. Ketika Nabi Muhammad masih hidup, rasa teosentrisme tersebut masih melekat sangat kuat dan berkembang. Namun semenjak nabi wafat, penyandaran terhadap Allah berkurang dan lambat laun beralih kepada antroposentrisme. Antroposentrisme adalah paham yang menempatkan manusia sebagai pusat, pangkal dan penentu segalanya. Hal yang demikian disebabkan karena pengaruh sisi negatif perkembangan sains dan teknologi yang tidak diimbangi dengan kekuatan iman. ${ }^{7}$

Oleh karena itu, peneliti merasa perlu untuk meneliti tentang Barakah melalui penafsiran Nouman Ali Khan lewat youtobenya karena youtobe merupakan media sosial yang banyak dimanfaatkan oleh masyarakat universal dan merupakan fenomena baru yang digunakan untuk menyingkap kajian ilmu al-Qur'an dan tafsir serta untuk mengetahui tentang pengaruhnya kepada masyarakat terhadap kajian tafsir yang lebih efektif di zaman sekarang.

\section{Pengertian Barakah}

Barakah terdiri atas ب- ب yang berarti banyaknya kebaikan pada sesuatu dan memiliki sifat menetap. ${ }^{8}$ Sedangkan menurut istilah, makna Barakah merupakan nilai tambahan dari Allah SW'T untuk siapapun dan bagi apapun yang dikehendaki-Nya. ${ }^{9}$ Selain itu, Ahsin Sakho Muhammad memberikan sedikit ulasan tentang Barakah, bahwa Barakah merupakan suatu hal yang luar biasa dan hanya terpusat kepada Allah serta sangat unggul sehingga tidak bisa ditandingi dengan apapun dan siapapun. ${ }^{10}$

\footnotetext{
${ }^{6}$ Tim Penulis, The 10th Anniversary Edition, the World's 500 Most Influential Muslim 2019, (Yordania: Jordan National Library, 2018), 178.

${ }^{7}$ Faisal Ismail, Islam, Doktrin, dan Isu-isu Kontemporer, (Yogyakarta: IRCiSoD, 2016), 329-331

${ }^{8}$ Ahsin Sakho Muhammad, Keberkahan al-Qur'an, (Yogyakarta: QAF Media Kreativa, 2017), 14.

9 Jamaluddin Kafie, Barokah, Apa, Dimana dan bagaimana?, (Pasuruan: P'T. Garoeda Buana Indah, 1999), 1.

${ }^{10}$ Ahsin Sakho Muhammad, Keberkahan al-Qur'an, Ibid., 14.
}

55 | Muṣhaf: Jurnal Tafsir Berwawasan Keindonesiaan Volume 1. Nomor 1, Desember 2020. 
Ar-Raghib al-Asfihani mengatakan bahwa Barakah merupakan tsubutul khair al-ilahi fi as-syai' yang bermakna bertambahnya kebaikan dari Allah kepada segala sesuatu. ${ }^{11}$ Sedangkan Ibnu Mandhur mengungkapkan tentang Barakah, yakni an-nama'u wa az-ziyadah artinya segala sesuatu yang tumbuh dan bertambah. Selain itu, Ibnu Mandhur mengungkit tentang keberkahan adalah ad-du'a li al-insan aughairibi bi al-Barakah (memberi doa kepada manusia atau segala sesuatu supaya mendapatkan Barakah ). ${ }^{12}$

Barakah bisa didapatkan secara langsung maupun secara tidak langsung. ${ }^{13}$ Hal demikian merupakan teknik tersembunyi dari keBarakah an tersebut. Misalnya ialah doa, doa merupakan salah satu cara untuk mendapatkan keBarakah an, karena doa merupakan interaksi manusia yang disampaikan secara langsung kepada Allah SWT. Sebagaimana yang dijelaskan Ibnu Mandhur tentang keberkahan. ${ }^{14}$ Berdoa merupakan meminta sesuatu kepada Allah, dan berdoa menghendaki adanya orang yang meminta, orang yang diminta dan sesuatu yang diminta. ${ }^{15}$ Sebagaimana nabi Zakariya meminta kepada Allah, dan Allah menceritakan dalam firman-Nya di QS. Ali Imran [03]: 38 .

Sedangkan yang dimaksud Barakah secara tidak langsung ialah sebuah upaya yang dilakukan seorang untuk mendapatkan keBarakah an dengan menggunakan perantara. Misalnya ialah sholawat kepada Nabi Muhammad SAW, contoh lain yang lebih spesific ialah bacaan tasyahud oleh Abu Mansur dalam kitab Lisanul Arab. Karena pada hakikatnya sholawat merupakan permohonan yang ditujukan kepada Allah SWT dengan perantara mengharap syafa'at dari Rasulullah SAW. Selain itu, sholawat merupakan keBarakah an yang mengandung kebahagiaan mutlak. ${ }^{16}$ Membaca sholawat sangat mudah, tanpa perlu bersuci atau terpaku pada gerakan dan ucapan tertentu, atau tanpa mengeluarkan uang seperti zakat, bahkan menahan makan dan minum seperti puasa. Oleh karena itu, keistimewaan membaca sholawat ialah pasti diterima walau seperti apapun dan bagaimanapun keadaannya. ${ }^{17}$

Disisi lain, ada beberapa hal dalam khazanah ke-Islaman yang menjadi pokok acuan dalam pembahasan Barakah, mulai dari segi subjek Barakah ,

${ }^{11}$ Abu al-Qasim al-Husayn bin Muhammad al-Raghib al-Asfihani, Mufradat al-Fadh al-Qur'an Juг II, (Damaskus: Daar al-Qolam, t.th), 69.

12 Abi Fadhal Jamaluddin Muhammad bin Mukarrom Ibnu Mandhur, Lisanul Arab Juz X, (Beirut: Daru Shodir, t.th), 395.

${ }^{13}$ Jamaluddin Kafie, Barokah, Apa, Dimana dan bagaimana?, Ibid., 18.

${ }_{14}$ Abi Fadhal Jamaluddin Muhammad bin Mukarrom Ibnu Mandhur, Lisanul Arab Juz X, Ibid., 395-396.

${ }^{15}$ Muhammad Mutawalli Asy-Sya'rawi, Hadis Qudsi Pilihan, (Jakarta: PT Zaytuna Ufuk Abadi, 2015), 70-71.

${ }^{16}$ Ibid., 396.

${ }^{17}$ Nadirsyah Hosen, Saring Sebelum Sharing, (Yogyakarta: PT Bentang Pustaka, 2019), 269-270.

56 | Muṣhaf: Jurnal Tafsir Berwawasan Keindonesiaan Volume 1. Nomor 1, Desember 2020. 
Perspektif Barakah Dalam Kesarjanaan Muslim Barat,

media Barakah dan objek Barakah. Unta nabi Muhammad SAW yang bernama al-Qashwa adalah salah satu contoh dari kajian subjek Barakah. Karena pada saat itu, enam tahun berlalu sejak kaum muhajirin meninggalkan kota Makkah. Dan kota Madinah yang ditempatinya sudah penuh ketentraman dari kerusuhan orang-orang munafik, Yahudi maupun masyarakat Badui yang memusuhi berbalik mengikutinya.

Nabi Muhammad SAW bermimpi menyaksikan dirinya dan para sahabat memasuki Masjidil Haram dalam keadaan aman. Oleh karena itu, beliau merasa bahagia dan bertekad untuk mengunjungi tanah air. Sehingga selang beberapa waktu, Rasulullah dan kaum muslim di Madinah berhadapan dengan kaum musyrik Makkah untuk mengadakan perjanjian, tepatnya ialah di Hudaibiyah. Maka dinamakanlah perjanjian tersebut dengan perjanjian Hudaibiyah.

Ketika itu, kaum Quraisy tidak menerima kedatangan beliau dan para sahabatnya. Maka tindakan yang dilakukan kaum musyrik Makkah ialah menghalangi jalan kaum muslimin.

Ketika Nabi Muhammad SAW mengetahui hal itu, Beliau memilih jalan tandus dan berliku hingga sampai di Hudaibiyah. Tibanya disana, unta beliau yang bernama al-Qashwa berhenti dan duduk. Para sahabat berkata "Unta al-Qashwa terkena penyakit.", namun Rasulullah berkata:

"Al-Qashwa tidak lelah dan itu bukan kebiasaannya, tetapi dia ditahan oleh Allah yang menahan pasukan Gajah saat ingn menyerang Makkah. Demi jiwa Muhammad yang berada di tangan-Nya, tidaklah mereka meminta sesuatu dariku untuk. menyambung silaturrabim dan mengagungkan Tanab Suci melainkan aku akan penubi permintaan mereka." (HR. Bukhari 2731 \& 2732). ${ }^{18}$

Adapun contoh dari media Barakah ialah pembahasan ziaroh kubur. Pada masa awal Islam, Rasulullah memang melarang umat Islam untuk melakukan ziaroh Kubur. Hal ini dimaksudkan untuk menjaga aqidah umat Islam. Rasulullah khawatir kalau ziaroh kubur diperbolehkan, umat Islam akan percaya dan menjadi penyembah kuburan. Setelah aqidah umat Islam kuat,

${ }^{18}$ Muhammad Sameh Said, Muhammad Sang Yatim, (Bandung: Cordoba. 2002), 295 dan 311. Lihat Abi Fadhal Jamaluddin Muhammad bin Mukarrom Ibnu Mandhur, Lisanul Arab Juz X, Ibid., 396. Lihat juga Abu al-Qasim al-Husayn bin Muhammad al-Raghib al-Asfihani, Mufradat al-Fadh al-Qur'an Juz II, Ibid., 69. Pada tiga literatur tersebut, cerita unta al-Qashwa merupakan bentuk keberkahan dari Allah kepada semua pasukan muslim yang dipimpin nabi Muhammad SAW agar tidak melanjutkan perjalanannya. Selain itu, ketiga penulis tersebut menuturkan bahwa kejadian tersebut merupakan asal usul barokah. Sebagaimana dikatakan oleh Abu alأصل البرك صدر البعير وإن استعمل في غيره Qhasim al-Husayn bin Muhammad al-Raghib al-Asfihani yaitu dan pemaparannya Abi Fadhal Jamaluddin Muhammad bin Mukarrom Ibnu Mandhur ialah وهو من برك البعير إذا أناخ في موضع فازمها وتطلق البركة أيضا على الزّيادة, والأصل الأول.

57 | Muṣhaf: Jurnal Tafsir Berwawasan Keindonesiaan

Volume 1. Nomor 1, Desember 2020. 
dan tidak ada kekhawatiran untuk berbuat syirik, Rasulullah membolehkan para sahabatnya untuk melakukan ziaroh kubur. Karena ziaroh kubur dapat membantu orang yang hidup mengingat saat kematiannya. Rasulullah bersabda:

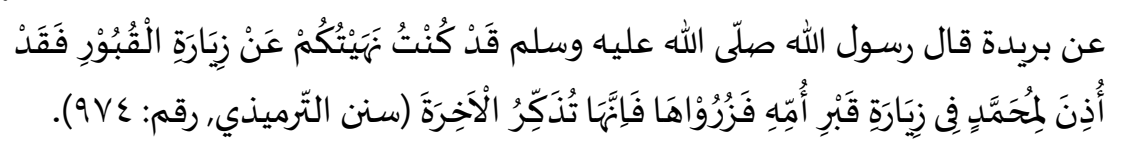

"Dari Buraidah ia berkata, Rasulullah SAW bersabda, "Saya pernah melarang kamu berziaroh kubur. Tapi sekarang, Muhammad telah diberi izin untuk berziaroh ke makam ibunya. Maka sekarang, berziarohlah! Karena perbuatan itu dapat mengingatkan kamu pada akhirat." (Sunan at-Trimidzi, 9741).

Dari hadis di atas, telah dijelaskan bahwa ziaroh kubur diperbolehkan. Tujuan ziaroh kubur ialah mengharapkan Barakah kepada Allah jika ahli kubur yang diziarohi merupakan orang-orang shaleh dan ahli melakukan kebaikan. ${ }^{19}$ Berikut hadisnya:

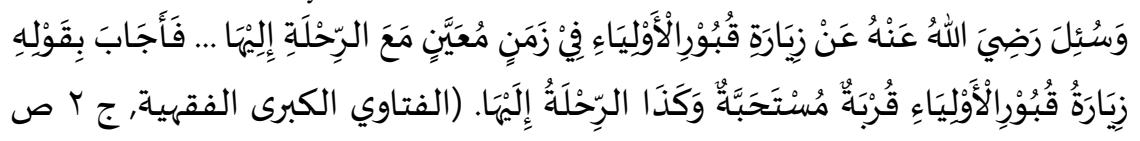

"Beliau ditanya tentang berziaroh ke makam para wali pada waktu tertentu dengan melakukan perjalanan khusus ke makam mereka. Beliau menjawab, berziaroh ke makam para wali adalah ibadah yang disunnahkan. Demikian pula dengan perjalanan ke makam mereka." (Al-Fatawi al-Kubra al-Fiqhiyyah, juz II, hal 24). ${ }^{20}$

Tujuan lain dari ziaroh kubur ialah untuk memenuhi hak ahli kubur untuk diziarohi, karena orang yang sudah meninggal akan merasa senang dengan kedatangan orang-orang yang masih hidup. ${ }^{21}$

Adapun objek Barakah yang disajikan oleh penulis ialah bekam. Hal itu dikarenakan Rasulullah SAW memiliki berbagai metode untuk mengobati banyak penyakit. Salah satu contohnya ialah bekam. Bekam merupakan suatu tindakan mengeluarkan penyakit maupun darah kotor. Masyarakat muslim dianjurkan untuk melakukan bekam satu kali seumur hidup sebagai upaya mencegah penyakit bahkan mengobati penyakit. Anjuran berbekam juga

${ }_{19}$ Muhammad Idrus Ramli, Wahabi Gagal Faham Jilid-2, (Pasuruan, Sidogiri Penerbit, 2018), 503.

${ }^{20}$ Muhyiddin Abdusshomad, Figh Tradisionalis, (Malang: Pustaka Bayan, 2014), 215-216.

${ }^{21}$ Muhammad Idrus Ramli, Wahabi Gagal Faham Jilid-1, (Pasuruan, Sidogiri Penerbit, 2018), 476.

58 | Muṣhaf: Jurnal Tafsir Berwawasan Keindonesiaan

Volume 1. Nomor 1, Desember 2020. 
disampaikan oleh para malaikat kepada Rasulullah ketika peristiwa isra' mi'raj. Adapun hadis tentang bekam ialah:

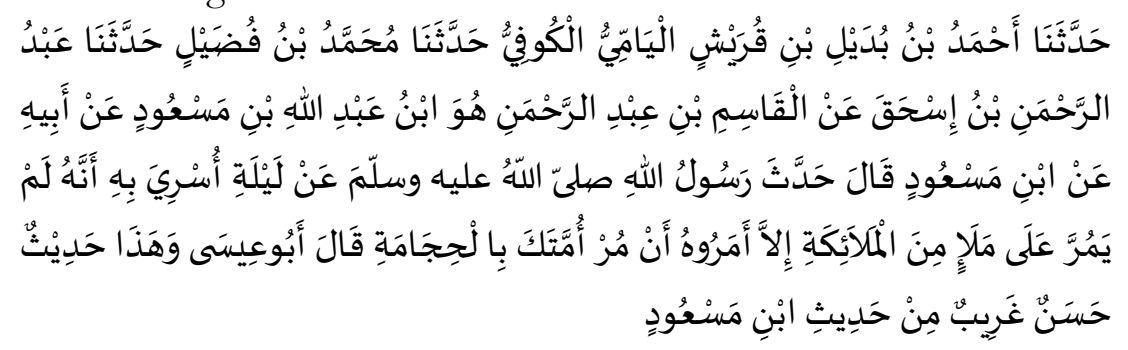

"Telah menceritakan kepada kami [Ahmad bin Budail bin Quraisy Al Yami Al Kufi], telah menceritakan kepada kami [Muhammad bin Fudlail], telah menceritakan kepada kami [Abdurrahman bin Ishaq] dari [Al Qasim bin Abdurrahman] ia adalah Ibnu Abdullah bin Mas'ud, dari [bapaknya] dari [Ibnu Mas'ud] ia berkata: Rasulullah SAW berkisah tentang malam isra' mi'raj, dan sesungguhnya tidaklah beliau melewati sekelompok malaikat kecuali mereka semua menyuruh beliau untuk memerintahkan umatnya berbekam. Berkata Abu Isa: Ini merupakan hadis Hasan gharib dari hadisnya Ibnu Mas'ud." (Hadis Tirmidzi No. 1977). ${ }^{22}$

Hadis diatas menerangkan tentang anjuran berbekam sebagaimana yang diterangkan oleh Rasulullah SAW, namun ada riwayat hadis lain yang menerangkan bahwa berbekam lebih baik dilaksanakan sebelum makan karena hal tersebut mengandung Barakah , yaitu:

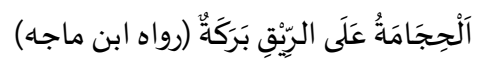

"Berbekam sebelum makan apa-apa adalah Barakah" (Hadis Riwayat Ibnu Majah). ${ }^{23}$

Sedangkan pembahasan Barakah yang terdapat dalam al-Qur'an sangatlah banyak dan luas, seperti halnya kisah nabi Allah yang sangat memberi panutan hingga keberkahan kepada umatnya. Selain itu, ada beberapa tempat atau benda yang mengandung keberkahan, seperti Masjidil Haram sebagaimana dijelaskan dalam QS. Ali Imran [03]: 96, bahwasanya pada ayat tersebut dijelaskan bahwa Masjidil Haram adalah tempat pertama yang dibangun untuk seluruh manusia yang merupakan tempat untuk menyembah Allah semata. Sedangkan contoh tempat yang kedua ialah Masjidil Aqsha bahwasanya ditegaskan tentang Masjidil Aqsha di Palestina atas kejadian isra'

${ }^{22}$ Flori Ratna Sari, dkk., Bekam Sebagai Kedokteran Profetik dalam Tinjanan Hadis, Sejarah dan Kedokteran Berbasis Bukti, (Depok: PT RajaGrafindo Persada, 2018), 71-73.

${ }^{23}$ Jamaluddin Kafie, Barokah, Apa, Dimana dan bagaimana?, Ibid., 15.

59 | Muṣhaf: Jurnal Tafsir Berwawasan Keindonesiaan

Volume 1. Nomor 1, Desember 2020. 
Perspektif Barakah Dalam Kesarjanaan Muslim Barat,

mi'raj nabi Muhammad SAW. Masjidil Aqsha merupakan tempat yang diberkahi karena para Nabi dan para Rasul, sejak zamannya Nabi Musa, Nabi Daud dan Nabi Sulaiman telah menyampaikan wahyu dari Allah. Maka dari itu, Nabi Muhammad SAW dibawa oleh malaikat ke tempat itu sehingga dipertemukan kepada arwah-arwah beliau serta mengimami sholat sebelum diangkat ke langit untuk menuju Sidratul Muntaha, ${ }^{24}$ hal itu dijelaskan dalam QS. Al-Isra'[17]: 1.

\section{Nouman Ali Khan: Biografi dan Corak Penafsirannya}

Nouman Ali Khan merupakan seorang muslim kelahiran Jerman yang berdomisili di Amerika Serikat, tepatnya pada 04 Mei 1978 di Berlin. Beliau merupakan salah satu muslim yang sangat berpengaruh, baik bagi kalangan Amerika sendiri maupun bagi kalangan negara lainnya. ${ }^{25}$

Ayahnya merupakan seorang diplomat dan mengharuskan Nouman Ali Khan sering berpindah Negara. Pada masa kecilnya beliau belajar di Jerman, namun ketika menginjak pada kelas II sampai kelas VIII, beliau pindah ke Arab Saudi tepatnya pada salah satu sekolah Pakistan yang terdapat disana. Pada kesempatan belajar tersebut, bahasa yang digunakan dalam sekolahnya merupakan bahasa Urdu. Bahasa Urdu merupakan bahasa ibu bagi Nouman Ali Khan. ${ }^{26}$ Selain itu, pada tahun 1993 Nouman belajar tentang grammar bahasa Arab di Pakistan karena meraih beasiswa 10 pelajar terbaik di National Arabic Studies Board Examinations. ${ }^{27}$

Hingga memasuki jenjang menengah atas, beliau pindah ke negara Amerika Serikat, tepatnya di salah satu kota terbesar, yakni New York. Disanalah Nouman sering belajar dengan masyarakat non-muslim sehingga membuat dirinya semakin jauh dari budaya Islam. ${ }^{28}$ Selain itu, Nouman bergabung dengan mahasiswa non muslim dan mengikuti kelompok yang mengomentari tentang Islam serta memperdebatkannya. Pada awal bergabung, pemikiran Nouman tentang Islam semakin tidak terkandali oleh imannya, namun setelah sekian lama berada dalam lingkup tersebut, Nouman memiliki inspirasi kuat untuk meluruskan fikirannya kepada ajaran Islam. ${ }^{29}$

\footnotetext{
${ }^{24}$ Hamka, Tafsir al-Az̧har Juz VI, Ibid., 3999-4001.

${ }^{25}$ Moh. Azwar Hairul, “Tafsir al-Qur'an di Youtobe”, Al-Fanar: Jurnal Ilmu al-Qur'an dan Tafsir, 2 (28 Agustus, 2019), 91-92.

${ }^{26}$ Ibid.

${ }^{27}$ bttp:// wmw.nakcollection.com/naks-biography.btml diakses 01 Agustus 2019.

${ }^{28}$ Moh. Azwar Hairul, “Tafsir al-Qur'an di Youtobe”, Al-Fanar: Jurnal Ilmu al-Qur'an dan Tafsir, 2 (28 Agustus, 2019), 91-92.

29 bttps:// www.kompasiana.com/ ziaulkausar/ 5 af08a68caf7db4b1d44c9d3/nouman-ali-khan-pakartafsir-terkenal-ke-indonesia diakses 08 Mei 2018.
}

60 | Muṣhaf: Jurnal Tafsir Berwawasan Keindonesiaan Volume 1. Nomor 1, Desember 2020. 
Dalam perjalanan memperdalam ilmu agama Islam, tepatnya pada tahun 1999, Nouman diajak salah satu temannya yang masih kuat keimanannya untuk mengikuti program Islami yang dibawakan oleh seorang ilmuan muslim yang sedang mengadakan kunjungan mengajar ke Amerika Serikat dalam bidang Tafsir dan Bahasa Arab, yaitu Dr. Abdus Samie. Beliau merupakan pendiri Qur'an College yang berasal dari Faisalabad Pakistan. Pada awalnya, Nouman hanya berfikir untuk menyimak dan mengkritisi tentang penjelasan Dr. Abdus Samie terkait seputar Islam, namun ketika Dr. Abdus Samie melantunkan beberapa kalam Ilahi-Nya, keyakinan dan tekad Nouman untuk mempelajari Islam sangat kuat sehingga Dr. Abdus Samie menjadi figur yang sangat mempengaruhinya. ${ }^{30}$

Setelah beberapa tahun kemudian, Nouman mengembangkan metode pendekatan gramatikal al-Qur'an. Nouman kemudian mendedikasikan ilmunya dalam mengajar tentang Bahasa Arab klasik hingga modern di Nassau Community College selama enam tahun lebih sehingga muridnya sebanyak 10.000 dari berbagai negara. ${ }^{31}$

Pada tahun 2005, Nouman memulai Bayyinah di laptopnya untuk mengajar dasar-dasar bahasa Arab klasik di area New York dan New Jersey, kemudian merilis program Tajwid dan Reading Essentials bersama Wisam Sharieff. ${ }^{32}$ Kemudian di tahun 2006, Nouman mendirikan Bayyinah Institute yang terletak di Dallas Forth Worth International dan Masjid Irving. Disamping menyebarluaskan dakwahnya via internet, Nouman juga berkeliling pada 40 lokasi untuk mempromosikan dakwahnya sebagai acuan media via sosial. Tepat pada tahun 2007, Nouman bertemu dengan Abdul Nasir Jangda yang juga ikut bergabung dengan Bayyinah serta mengajar kelas pertamanya di Vermont.

Ketika musim panas di tahun 2009, Bayyinah pindah tempat ke Dallas, Texas. Waktu itu, nouman memiliki ide untuk mendirikan kampus, dan pada tahun 2010, setelah mencari lokasi lebih dari 100 tempat, Nouman memutuskan untuk membangun kampus Bayyinah di dekat Dallas/Forth Worth International Airport dan Masjid Irving dengan menyewa 11.000 meter persegi yang digunakan untuk mendirikan kampus. ${ }^{33}$

Pada kajian-kajian yang disampaikan oleh Nouman di Youtobe bisa diakses melalui situs bayyinah.com. pengalamannya bekerja di bidang industri

30 bttps://nakindonesia.com/2017/01/05/biografi-nouman-ali-khan/ diakses 05 Januari 2017. Lihat Moh. Azwar Hairul, “Tafsir al-Qur'an di Youtobe”, Al-Fanar: Jurnal Ilmu al-Qur'an dan Tafsir, 2, ibid., 93.

${ }^{31}$ Ibid.

32 bttps://nakindonesia.com/2017/01/05/biografi-nouman-ali-khan/ diakses 05 Januari 2017.

${ }^{33}$ Ibid.

61 | Muṣhaf: Jurnal Tafsir Berwawasan Keindonesiaan Volume 1. Nomor 1, Desember 2020. 
teknologi membuat Nouman memiliki banyak pandangan dan bekal unuk dakwahnya.

Terdapat dua channel youtobe yang dikelola, yaitu Bayyinah Institute sebagai channel utama dan partnernya yang bernama Channel Qur'an Weekly. Bayyinah Institute dibuat pada tanggal 16 Februari 2009 dan masih aktif sampai sekarang. Sedangkan Channel Qur'an Weekly dibuat pada tanggal 24 Oktober 2009 dan terakhir beroperasi pada tanggal 23 September 2016. Pada channel Bayyinah Institute, berisi 533 video yang terbagi pada 32 playlist dan diputar hampir 70 juta viewers. ${ }^{34}$ Beda halnya dengan Channel Qur'an Weekly, walau unggahan video diberhentikan, namun channel tersebut tetap ditonton oleh 30 juta viewers. Persamaan kedua channel ini adalah berisi tentang kajian Islam, namun yang membedakan karena terdapat satu rubrik yang khusus pada pembacaan al-Qur'an dengan judul "Qur'an Recitation" yang diisi oleh beberapa pembicara. ${ }^{35}$

Semua kajian yang disampaikan oleh Nouman, diterima dengan baik oleh masyarakat muslim di Amerika pada umumnya serta di seluruh belahan dunia yang menikmatinya walaupun apada awalnya banyak masyarakat sekitar yang skeptis atas perjalanan dakwahnya. Hal itu sebagaimana disampaikan oleh Pew Research Center (PRC) bahwa masyarakat muslim yang berada di Amerika masih memiliki karakteristik yang didominasi oleh kepercayaan yang sangat kental kepada ajaran al-Qur'an. Sebagian besar masyarakat disana memiliki pemikiran bahwa al-Qur'an hanya cukup dipahami secara tekstual, namun sebagian kecil dari mereka berpendapat bahwa al-Qur'an bisa dipahami dengan luas sesuai dengan teks dan konteksnya. Hal yang demikian mejadi titik acuan bahwa pada hakikatnya masyarakat muslim di Amerika masih paham terkait tentang kajian al-Qur'an. Hemat penulis, kehadiran Nouman di Amerika sangat patut diapresiasi karena menambah semangatnya iman kaum muslim disana. ${ }^{36}$

Pada tahun 2019, Nouman dinobatkan menjadi salah satu muslim yang berpengaruh dari 500 muslim lainnya oleh The Royal Islamic Strategic Studies Centre. Sedangkan dari Indonesia, diwakili oleh bapak Quraish Shihab (mufassir kontemporer), Abdullah Gimnastiar (Indonesia's most popular preacher), dan bapak Haidar Bagir (CEO of Mizan Publishing Company). ${ }^{37}$

Bukan hanya itu, maraknya penceramah via digital mengharuskan masyarakat untuk pintar dalam memilah figurnya agar tidak salah memetik

\footnotetext{
${ }^{34}$ Moh. Azwar Hairul, “Tafsir al-Qur’an di Youtobe”, Al-Fanar: Jurnal Ilmu al-Qur'an dan Tafsir, 2, ibid., 94.

35 Ibid. 93-94.

36 Ibid., 93-94.

${ }^{37}$ Tim Penulis, The 10th Anniversary Edition, the World's 500 Most Influential Muslim 2019, (Yordania: Jordan National Library, 2018), 174, 178 dan 182.
}

62 | Muṣhaf: Jurnal Tafsir Berwawasan Keindonesiaan Volume 1. Nomor 1, Desember 2020. 
ilmu. Sebuah akun twitter dengan nama Ziatuwel menerangkan dalam sebuah opininya tentang rekomendasi ngaji tafsir di sosial media, khususnya di youtobe, hal itu diinspirasi karena munculnya banyak penceramah yang tidak berkapasitas keilmuan dan hanya sembarangan menafsirkannya. Terdapat tiga tokoh yang ditampilkan, yaitu Syaikh Mutawalli Sya'rawi, ustadz Nouman Ali Khan, Gus Bahauddin. Disisi lain, dia menambahkan subyek lain sebagai tawaran mepada masyarakat, misalnya bapak Quraish Shihab, ustadz Adi Hidayat, dll. ${ }^{38}$

Menurut pandangan beberapa intelektual, Nouman Ali Khan merupakan sosok penceramah yang santai dan menyampaikan dakwahnya dengan berbagai perumpamaan sehingga esensi tentang Islam yang diajarkannya sangat mudah diterima dan difahami. ${ }^{39}$

Adapun corak yang dibawakan oleh Nouman Ali Khan ialah adabi ijtima'i dengan pendekatan linguistik. Corak tafsir adabi ijtima’i terdiri dari dua kata, yaitu filologi dan sastra (tafsir adabi) dan kemasyarakatan (ijtima'i). Sedangkan makna etimologisnya ialah sebuah tafsir yang berorientasi pada sosial kemasyarakatan atau bisa disebut dengan tafsir sosio-kultural. ${ }^{40}$ Biasanya, corak adabi ijtima'i mengungkapkan segi balaghah al-Qur'an dan kemu'jizatannya.41 Sebagian ulama mengatakan bahwa corak adabi ijtima’i termasuk pada metodologi tafsir bi al-ra'yi. ${ }^{42}$ Adapun contoh tafsir yang menggunakan corok adabi ijtima’i ialah tafsir al-Manar, hasil pemikiran Syeikh Muhammad Abduh yang dibukukan oleh Muhammad Rasyid Ridha. ${ }^{43}$

Sedangkan yang dimaksud dengan pendekatan linguistik ialah dengan menggunakan bahasa yang difahami oleh orang lain. Sebab al-Qur'an mengandung dua bahasa, yaitu bahasa secara haqiqi (literal) dan majazi (metafor) .4

\section{Metodologi Penafsiran Nouman Ali Khan}

Metodologi merupakan salah satu sarana yang sangat penting untuk mencapai tujuan yang telah ditetapkan, baik berhubungan dengan pemikiran dan

38 https:// threadreaderapp.com/thread/1028673391086120961.html)Thread diakses 2019.

39 https://www.republika.co.id/berita/koran/news-update/16/10/28/ofqog39-membacadakwah-nouman-ali-khan diakses pada tanggal 28 Oktober 2016.

Lihat https://bincangsyariah.com/khazanah/nouman-ali-khan-tokoh-muslim-berpengaruhasal-pakistan/diakses pada tanggal 06 Mei 2018.

${ }^{40}$ M. Karman Supiana, Ulumul Qur'an, (Bandung: Pustaka Islamika, 2002), 316-317.

${ }^{41}$ Anhar Anshori, Pengantar Ulumul Qur'an, ibid., 97.

42 Ibid., 93.

${ }^{43}$ Acep Hermawan, Wawasan al-Qur'an, Tafsir Maudhu'i atas Berbagai Persoalan Umat, (Bandung: Mizan, 1997), 116-117.

${ }^{44}$ Kusroni, "Mengenal Pendekatan, Metode, dan Corak dalam Penafsiran al-Qur'an”, Jurnal Kaca Jurusan Ushuluddin STAI Al Fithrah, 1 (Februari, 2019), 89.

63 | Muṣhaf: Jurnal Tafsir Berwawasan Keindonesiaan

Volume 1. Nomor 1, Desember 2020. 
penalaran akal. Dalam kaitan ini, maka metode penelitian tafsir ialah suatu cara yang teratur dan terpikir baik-baik untuk menelusuri kembali berbagai penafsiran ayat-ayat al-Qur'an yang pernah diberikan oleh ulama atau untuk mendapatkan penafsiran baru yang cocok dengan perkembangan zaman, tidak keluar dari yang dimaksudkan Allah dalam ayat-ayat al-Qur'an. Metodologi penafsiran berisi tentang kaidah-kaidah atau cara-cara yang harus dikuasi oleh seorang mufassir. ${ }^{45}$

Pada penafsirannya, Nouman Ali Khan condong pada pemikirannya Dr. Abdus Samie, hal itu sebaimana dijelaskan pada biografi diatas. Sedangkan teknik penafsirannya menggunakan maudhu'i (tematik). Metode tafsir tematik adalah suatu upaya dalam menafsirkan al-Qur'an dengan mengambil tematema tertentu, lalu mengumpulkan semua ayat yang berkaitan dengan tema tersebut, kemudian dijelaskan satu persatu dari sisi semantis serta penafsirannya dan dihubungkan satu dengan yang lain sehingga membentuk suatu gagasan yang utuh dan komprehensif mengenai pandangan al-Qur'an terhadap tema yang dikaji. Selain itu, metode tematik merupakan trend baru dalam menafsirkan al-Qur'an era modern-kontemporer. ${ }^{46}$

Setelah itu, mufassir menentukan ayat-ayat yang dipilih sesuai dengan masa turunnya, menjelaskan asbabun nuzulnya, menjelaskan makna dan tujuannya, mengkaji seluruh segi dan apa yang dapat diistimbatkan darinya, baik dari segi i'rab, balaghah, i'jaz, maupun yang lain. ${ }^{47}$

Sedangkan dalam bentuk penafsirannya menggunakan ra'yu (pemikiran atau akal). Mengenai hal ini, para ulama' menegaskan bahwa tafsir bi ar-ra'yi ada yang diterima serta ada yang ditolak. Hal itu bisa dilihat dari kualitas penafsirannya serta memenuhi syarat-syarat tertentu:

Pertama, mencari makna al-Qur'an dari redaksi al-Qur'an. Jika tidak menemukan, maka di dalam hadis, jika tidak ditemukan maka hendak mencari dari pendapat qaul sahaba.

Kedua, apabila cara-cara di atas tidak dapat menafsirkan al-Qur'an dengan jelas atau tidak sesuai dengan konteks masa kini, maka caranya menafsirkan harus memperhatikan makna-makna lafadz yang tunggal, lalu lafadz tersebut ditinjau dari segi bahasa, shorrof, isytiqaq dengan memperhatikan makna yang dipakai di masa al-Qur'an diturunkan, memperhatikan susunan-susunan kalimat dari segi i'rab dan balaghah serta meresapi keindahannya dengan kekuatan ilmu bayan, mendahulukan makna

\footnotetext{
${ }^{45}$ Nashruddin Baidan dan Erwati Aziz, Metodologi Khusus Penelitian Tafsir, (Yogyakarta: Pustaka Pelajar, 2016), 14.

${ }^{46}$ Abdul Mustaqim, Metode Penelitian al-Qur'an dan Tafsir, (Yogyakarta: Idea Press Yogyakarta, 2014), 19.

${ }^{47}$ Anhar Anshori, Pengantar Ulumul Qur'an, (Yogyakarta: Lembaga Pengembangan Studi Islam Universitas Ahmad Dahlan, 2012), 99-100.
}

64 | Muṣhaf: Jurnal Tafsir Berwawasan Keindonesiaan Volume 1. Nomor 1, Desember 2020. 
Perspektif Barakah Dalam Kesarjanaan Muslim Barat,

haqiqi atas makna majazy, memperhatikan asbab an-nuzul, nasikh mansukh, ilmu qiro'at, memperhatikan historis al-Qur'an, memperhatikan korelasi antar ayat, memperhatikan apa yang dimaksud dari siyaqul kalam, menyesuaikan tafsir dengan ilmu-ilmu yang telah positif benarnya, merenungkan makna yang dimaksud dan hukum-hukumnya sesuai syari'at, memelihara undang-undang tarjih diwaktu memerlukan tarjih.

Namun, kekurangan dari motode ini adalah: menjadikan petunjuk alQur'an yang bersifat parsial atau berpecah-pecah, cenderung pada pemikiran subjektif serta masuknya penafsiran isra'illiyat.48 Selain itu, Nouman jarang memaparkan tentang asbabun nuzul. Pada hakikatnya hal itu penting dikemukakan dalam memahami dan menafsirkan al-Qur'an. Selanjutnya, Nouman jarang mengutip dari mufassir lainnya sebagai rujukan dakwahnya, padahal hal yang demikian bisa menjadi kesinambungan keilmuan tafsir dari masa ke masa. ${ }^{49}$

\section{Makna Barakah Menurut Nouman Ali Khan}

Pada penafsiran tentang Barakah menurut Nouman Ali Khan, terdapat dua video yang penulis temukan, yaitu dilansir pada tahun 2013 yang bertempat di sebuah Masjid Malaysia, sedangkan pada tahun 2014 menjelaskan di studio Bayyinah Institute.

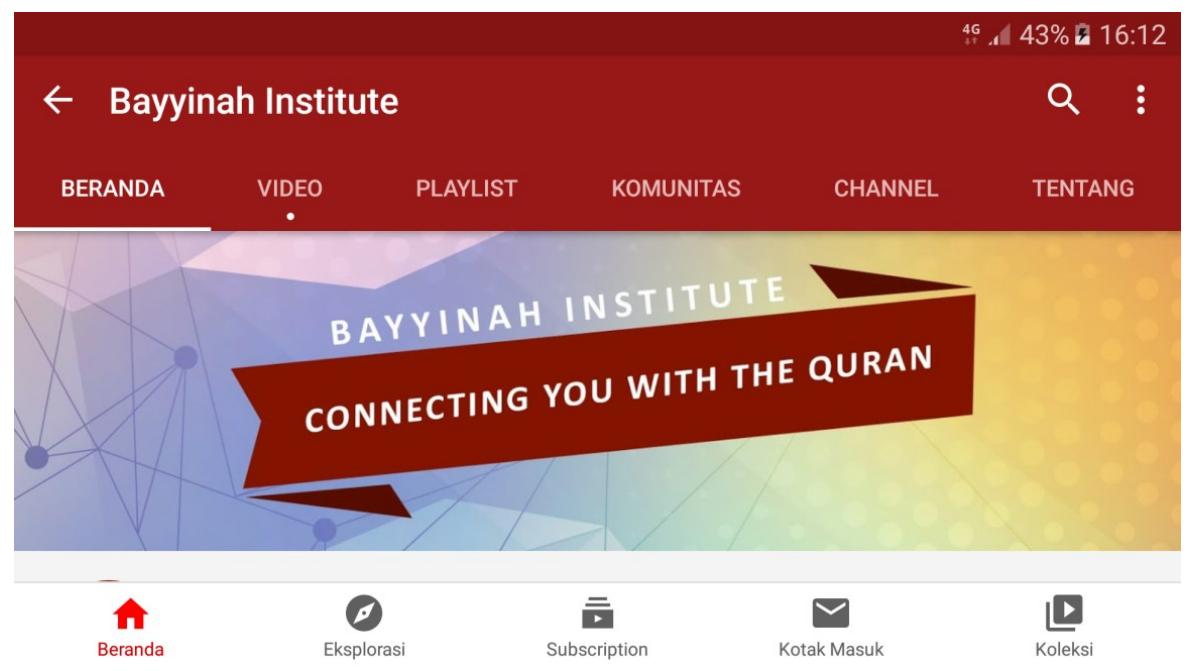

\footnotetext{
48 Anhar Anshori, Pengantar Ulumul Qur'an, Ibid., 92.

${ }^{49}$ Moh. Azwar Hairul, “Tafsir al-Qur'an di Youtobe”, Al-Fanar: Jurnal Ilmu al-Qur'an dan Tafsir, 2, ibid., 98.
}

65 | Muṣhaf: Jurnal Tafsir Berwawasan Keindonesiaan

Volume 1. Nomor 1, Desember 2020. 


\section{Lia Qurrota Aini}

Perspektif Barakah Dalam Kesarjanaan Muslim Barat,

Gambar 1: Tampilan awal situs youtobe Bayyinah Institute.

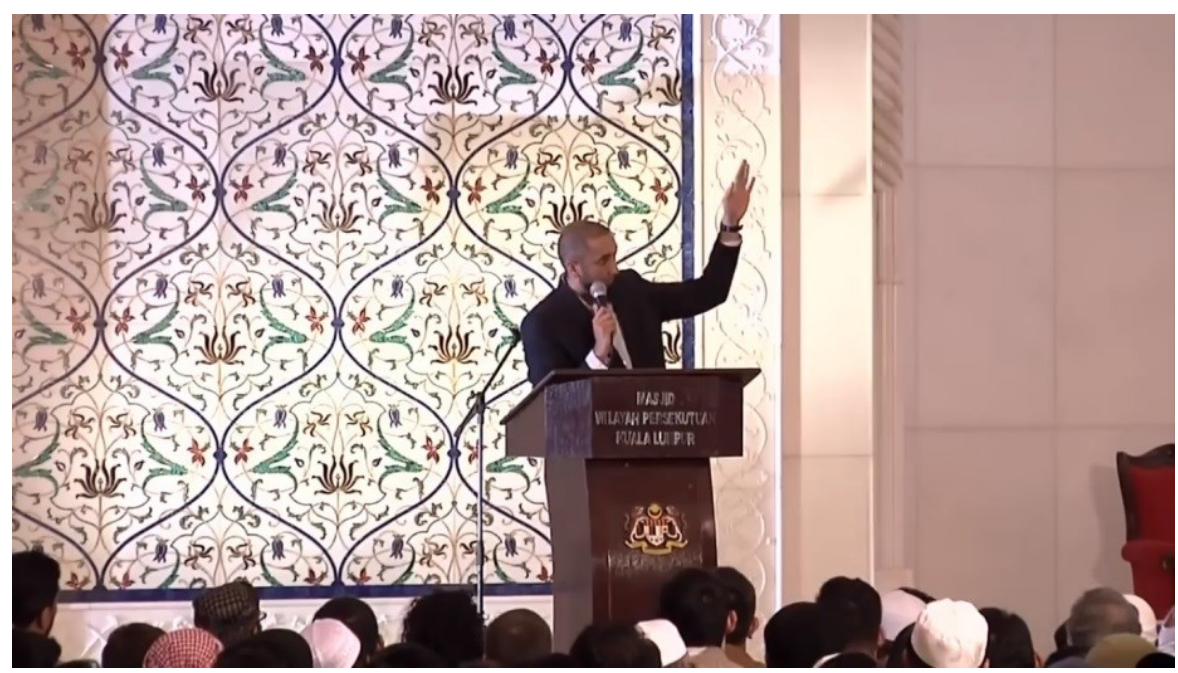

Gambar 2: Nouman Ali Khan ketika mengisi pengajian di Masjid Malaysia pada tahun 2013.50

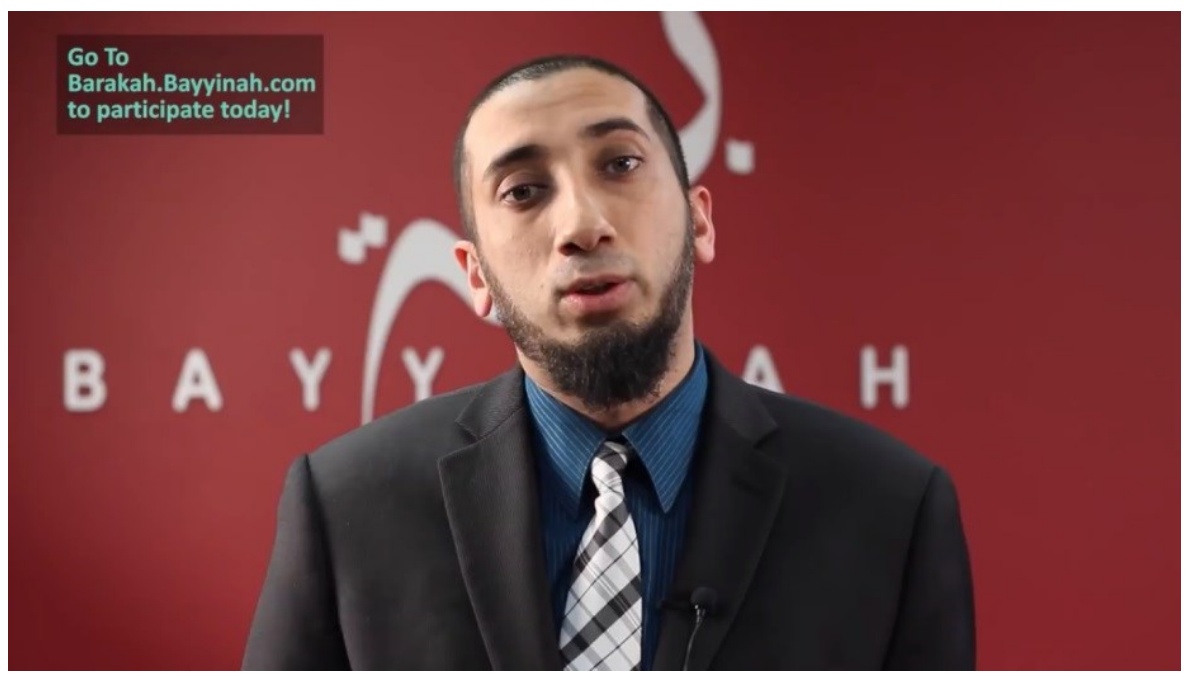

${ }^{50}$ https://youtu.be/dpXbn6LeIIQ diakses pada tanggal 16 Oktober 2013.

66 | Muṣhaf: Jurnal Tafsir Berwawasan Keindonesiaan

Volume 1. Nomor 1, Desember 2020. 
Gambar 3: Nouman Ali Khan ketika melakukan rekaman di Bayyinah Institute pada tahun 2014. ${ }^{51}$

Dalam dua waktu yang berbeda tersebut, Nouman mengkaitkan Barakah dengan dua ayat al-Qur'an, yaitu QS. Ar-Rahman [55]: 78 dan QS. At-Thalaq [65]: 03). Adapun penjelasan spesifik yang dikemukakan oleh Nouman ialah:

Barakah essentially has three meanings: First, suggest is growth and increase, when something has barakah it grows and it increases. Second, Barakah has something that continues that stays that stationary. Third, something that remains in its place it doesn't go anywhere, so not only is it continuing it is expected to remains. Allah says his name is full of Barakah, when you do something invoking his name when you say "Bismillahirrohmanirrohim" your small effort is going misteriously empowered. Allah will intervene and you will yield result you didn't expectrather result you couldn't imagined. The impact of Barakah : First, 60 or more students each batch filling it to capacity and quickly becoming the most successful full-time Arabic program for muslims in the United States Second, a number of graduates were some of the smartest, most talented, dedicated and sincere people that Nouman Ali ever met they didn't only graduate a students but become a part of the baena family as faculty and administration. Third, Bayyinah TV is launched and becomes a resource for thousands to learn from home their own time.

Maksud dari perkataan Nouman ketika diterjemahkan dalam bahasa Indonesia ialah, Barakah merupakan suatu hal yang bertumbuh dan berkembang dengan syarat membaca basmalah pada setiap suatu hal yang akan dilakukan atau dalam bahasa Arab disebut annama'u wa az-ziyadah.

Selain mengaitkan pada lafadz basmalah, Nouman juga mengkaitkan dengan surah ar-Rahman. Pada permulaan surah, Allah menyebut dirinya arRahman, dalam artian bahwa pada kalimat tersebut mengandung unsur Barakah . Yang kedua ialah pada ayat terakhir yang berbunyi Tabarasmu rabbuka dzal jalali wa al-ikrom, pada lafadz tabaroka memiliki makna penuh dengan Barakah , sedangkan kata jalal / jall hanya dimiliki oleh Allah yang artinya Maha Agung. Maka pada hakikatnya, ayat terakhir menjawab dari penyataan ayat pertama.

Disisi lain, Nouman memberikan beberapa contoh tentang Barakah yang dikaitkan pada zaman sekarang. Semisal tentang peningkatan

${ }^{51}$ https://youtu.be/dHR6i1iK8Tk diakses pada tanggal 17 April 2014.

67 | Muṣhaf: Jurnal Tafsir Berwawasan Keindonesiaan

Volume 1. Nomor 1, Desember 2020. 
perekonomian di Amerika Serikat yang langsung turun drastis, sehingga terdapat banyak alih pemerintahan dan membuat perekonomian berantakan. Yang kedua ialah, tentang busana yang sangat tren mendunia namun lekas lenyap. Sehingga Barakah tidak bisa dikendalikan dengan akal sehat, logika, bahkan perhitungan matematika.

Maka dari semua contoh yang diberikan oleh Nouman Ali Khan ialah memiliki keterkaitan dengan perkembangan sains dan teknologi sehingga membuat manusia lupa akan rasa syukur bahwa semua itu datang dari kehendak Allah SWT dan membuat nilai Barakah berkurang atau bahkan tidak bernilai lagi.

Beda halnya dengan penafsiran Hamka terkait surah ar-Rahman ayat terakhir tersebut. Beliau menafsirkan bahwa hanya Allah yang layak dimuliakan bukan didurhakai. Oleh karena itu kita sebagai hamba harus selalu berdzikir kepadanya. ${ }^{52}$

Jadi, perbedaan antara penafsiran Nouman Ali Khan dan Hamka tentang surag ar-Rahman ayat 78 ialah jika Nouman mengkaitkannya dengan pembahasan Barakah, sedangkan Hamka mengkaitkannya dengan berdzikir kepada Allah SWT.

\section{Pandangan Masyarakat Terkait Penafsiran Nouman Ali Khan Tentang Barakah}

Kajian tafsir di youtobe tersusun dalam bentuk komunikasi yang terdiri dari beberapa komponen, yaitu: mufassir yang bertindak sebagai komunikator, sajian tafsir yang disampaikan sebagai pesan, khalayak pendengar tafsir sebagai komunikan, dan dampak yang ditimbulkan dari penafsiran. ${ }^{53}$

Pada pembahasan ini, peneliti mengkaitkan dengan teori komunikasi massa yang terdiri dari tiga dimensi, yaitu: efek kognitif, efek afektif dan efek behavioral. Efek kognitif memberikan informasi kepada khalayak media sehingga bisa dipelajari. Sedangkan efek afektif ialah suatu hal yang berkaitan dengan sikap, emosi, perasaan dan minat yang muncul dari kahalayak media setelah menerima informasi yang disajikan oleh efek kognitif. Sedangkan yang terakhir ialah efek behavioral, yaitu sesuatu yang ditimbulkan ketika seorang sudah mengalami dua tahap sebelumnya, sehingga menghasilkan perubahan lebih baik pada bentuk perilaku, tindakan bahkan kegiatan. ${ }^{54}$

\footnotetext{
${ }^{52}$ Hamka, Tafsir al-Azhar Juz IX, (Singapura: Pustaka Nasional PTE LTD, 1989), 4298.

53 Onong Uchjana Effendy, Dinamika Komunikasi, (PT Remaja Rosdakarya: Bandung, 2004), 6.

${ }^{54}$ Suryanto, Pengantar Ilmu Komunikasi, (Bandung: CV Pustaka Setia, 2015), 196-198.

68 | Muṣhaf: Jurnal Tafsir Berwawasan Keindonesiaan Volume 1. Nomor 1, Desember 2020.
} 
Perspektif Barakah Dalam Kesarjanaan Muslim Barat,

\section{Efek Kognitif}

Pada dasarnya, mufassir merupakan komunikator yang menyampaikan pesanpesannya yang direspon langsung audiens yang berupa pemahaman akan adaya suatu informasi atau pengetahuan sesuai dengan kebutuhan penggunaannya. Efek kognitif yang diberikan oleh Nouman berupa suatu pengetahuan mencakup keagamaan yang terdapat dalam kandungan alQur'an.

Adapun efek kognitif oleh netizen yang terdapat pada penafsiran Barakah oleh Nouman ialah:

\section{$\equiv$ YouTube $^{\mathrm{ID}}$}

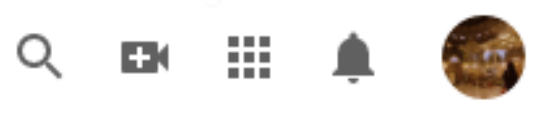

S

S Aqeel 7 bulan yang lalu

MashaaAllah BarakAllah so beautiful $\bullet$ I loved it so

much.... Allah give us all hidayah... ameen

It 1 al BALAS

Gambar 4: Komentar audiens

"MashaaAllah Barak. Allah so beautiful. I loved it so much.... Allah give us all bidayah...ameen". Maksud dari akun youtobe S Aqeel ialah sangat mengapresiasi terhadap penjelasan Nouman Ali Khan serta mendoakannya.

\section{$\equiv$ YouTube $^{\mathrm{ID}}$}
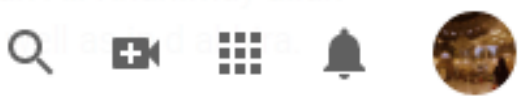

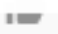

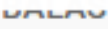

Humble Traveler 1 bulan yang lalu

Subpana Allah very informative video, helping me become a better practicing Muslim :D

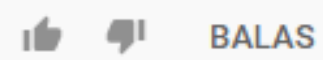

Gambar 5: Komentar audiens

"SubhanaAllah very informative video, helping me become a better practicing muslim". Arti dari comment-an Humble Traveler adalah SubhanaAllah, itu merupakan video yang sangat bagus. Dan latihlah saya untuk menjadi muslim yang baik. 
Perspektif Barakah Dalam Kesarjanaan Muslim Barat,

h hitsugaya captain 4 tahun yang lalu

soubhannalah, giving $9 \$$ to learn the Qur'an , to

understand it more every day trought his fantastic

work, and to permite in the same time to grow baraka

in this project is a gift to us inch'allah.

Gambar 6: Komentar audiens

\section{BALAS}

"SubhanaAllah, giving $9 \$$ to learn the Qur'an, to understand it more everyday trought his fantastic work, and to permite in the same time to grow Baraka in this project is a gift to us insyaAllah." Dalam paparannya, Hitsuga Captain mengutarakan bahwa dia mempelajari al-Qur'an setiap harinya dengan menghabiskan biaya yang banyak serta memohon kepada Allah agar diberikan Barakah atas pekerjaannya.

B BIA Dawah 5 tahun yang lalu

As-Salamu Alaikum Everyone, first, I would like to thank Bayyinah for giving us this opportunity to participate for their new campus. Anyone who would really like to learn Arabic to understand Quran better

\section{BALAS}

Gambar 7: Komentar audiens

"Assalamualaikum everyday, first, I would like to thank Bayyinah for giving us this opportunity to participate for their new campus. Anyone who would really like to learn Arabic to understand Quran better." Akun youtobe BIA Dawah menjelaskan bahwa dia sangat berterima kasih atas jasa Bayyinah yang diberikan oleh pihak kampus. Karena hal itu merupakan wadah bagi masyarakat yang ingin mempelajari bahasa Arab serta memahami al-Qur'an dengan baik.

Jadi, semua komentar yang disajikan diatas ialah termasuk keberhasilan Nouman Ali Khan dengan menjelaskan suatu pembahasan yang sangat mudah difahmi oleh khalayak sehingga mereka mengapresiasikannya melewati tulisan.

\section{Efek Afektif}

Efek afektif merupakan sebuah tahapan setelah efek kognitif. Hal ini berkaitan dengan emosional seorang audiens yang rasakan Nouman setelah menyimak penafsiran Nouman Ali Khan. Berikut pemaparannya: 


\section{Lia Qurrota Aini}

Perspektif Barakah Dalam Kesarjanaan Muslim Barat,

\section{A. Ibrahim Mohamed 5 tahun yang lalu \\ One of the best, most inspirational and motivational video I have seen in my entire life. "Barakah". Willing to be a part of Bayyinah In-shaa-Allah and help in its development.}

\section{I) 9 BALAS}

Gambar 8: Komentar audiens

"One of the best, most inspirational and motivational video I have seen in my entire life. "Barakab". Willing to be a part of Bayyinah in-shaa-Allah and help in its development." Sebuah komentar dari seorang yang sangat terinspirasi dan termotivasi setelah mendengarkan tentang penjelasan Nouman Ali Khan tentang Barakah .

Puteri Norathirah 3 tahun yang lalu

journey with the Quran make me more closer to

Allah. and thru that, Allah makes ease for me to learn

Arabic Quran from my ustadh and ustadh Nouman

Ali Khan (thru bayyinah tv).

\section{II BALAS}

Gambar 9: Komentar audiens

"Journey with the Quran make me more closer to Allah. And thru that, Allah ease for me to learn Arabic Quran from my ustadzah and ustadz. Nouman Ali Khan (thru Bayyinah tv)." Akun Puteri Norathirah memberi komentar kepada sebuah video yang disajikan Nouman Ali Khan tentang Barakah bahwasanya al-Qur'an membuat dirinya tenang dan lebih dekat kepada Allah SWT. Hal itu bermula ketika dia belajar al-Qur'an kepada Nouman Ali Khan melalui Bayyinah TV.

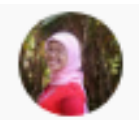

Wulan Kuswo 2 tahun yang lalu

my tears falling during this video...masya Allah....

\section{If}

Gambar 10: Komentar audiens

"My tears falling during this video...MasyaAllah..." Maksud dari komentar Wulan Kuswo ialah dia merasa sangat termotivasi kepada Nouman Ali Khan. Kesimpulan tentang semua komentar yang terdapat diatas menunjukkan bahwa penafsiran Nouman Ali Khan berhasil menyentuh emosional audiens. 


\section{Lia Qurrota Aini}

Perspektif Barakah Dalam Kesarjanaan Muslim Barat,

\section{Efek Behavioral}

Ketika efek afektif menyentuh emosional audiens, maka terjadilah efek behavioral, yaitu sebuah efek mampu memotivasi seorang untuk berubah lebih baik daripada sifat, sikap atu perilaku vang sebelumnva.
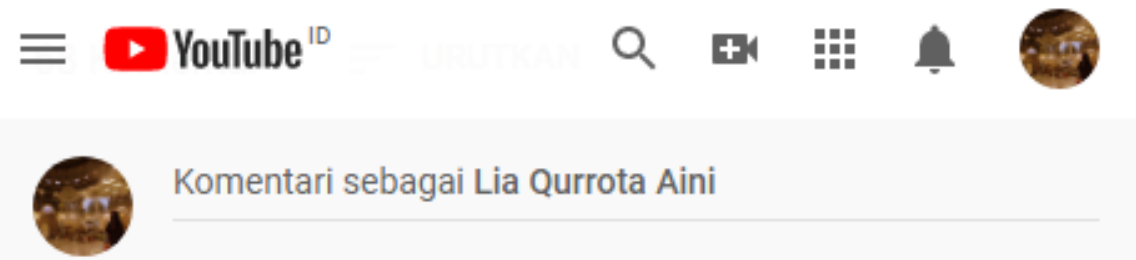

Komentari sebagai Lia Qurrota Aini

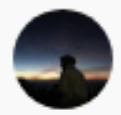

Fitria Dewianti 3 tahun yang lalu

Someone gifted me bayyinahTV subscription, and ever since my life has changed. May Allah grant him Firdaus al A'la coz if it wasn't for him I wouldn't learn much the quran and sunnah.

\section{$27 \quad$ II BALAS}

Gambar 11: Komentar audiens

"Someone gifted me bayyinah TV subscription, and ever since my life has changed. May Allah grant him firdaus al-A'la because if it wasn't for him I wouldn't to much the Quran and sunah." Fitria Dewianti merasakan perubahan dalam kehidupannya semenjak dirinya mengenal Bayyinah TV dan mempelajarinya.

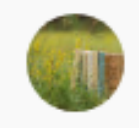

\section{Najoa B. 5 tahun yang lalu}

Everything I use for this dunya is lost here once it is finished. Everything I give for the pleasure of Allah is all I will have once I am gone.

\section{I BALAS}

Gambar 12: Komentar audiens

"Everything I use for this dunya is lost here once it is finished. Everything I give for the pleasure of Allab is all I will have once I am gone.'Semenjak mengenal Nouman Ali Khan melalui ceramahnya tentang Barakah, seseorang atas akun Najoa B. sangat menyesali kehidupannya karena dihabiskan oleh kesenangan semata. Oleh karena itu, keterangan yang terdapat pada semua komentar diatas dapat 
Perspektif Barakah Dalam Kesarjanaan Muslim Barat,

menunjukkan bahwa Nouman Ali Khan berhasil mengubah paradigma audiens melewati penafsirannya.

\section{Penutup}

Berdasarkan paparan data seta analisis yang telah dilakukan, penulis dapat menyimpulkan beberapa hal, diantaranya sebagai berikut:

Pada dua video pembahasan tentang Barakah yang dilansir di channel youtobe Bayyinah Institute, Nouman Ali Khan menjelaskan bahwa makna Barakah ialah suatu hal yang bertumbuh dan berkembang dengan syarat membaca basmalah pada setiap suatu hal yang akan dilakukan atau dalam bahasa Arab disebut an-nama'u wa az-ziyadah dengan mengkaitkan pada surah ar-Rahman ayat terakhir yang menunjukkan bahwa dalam Asma Allah terdapat Barakah .

Pandangan masyarakat terkait penafsiran Nouman Ali Khan tentang Barakah sangat memuaskan bagi mereka. Hal itu sebagaimana didasarkan pada teori komunikasi massa yang memiliki tiga point penting, yaitu: kognitif, afektif, behavioral. Tiga point tersebut diperoleh dari komentar yang terdapat pada dua channel penafsiran Barakah tersebut, mulai dari masyarakat yang baru mengetahui tentang makna dan pentingnya Barakah hingga masyarakat tersebut memiliki kemauan untuk berubah dan memperbaiki diri. 
Perspektif Barakah Dalam Kesarjanaan Muslim Barat,

\section{Daftar Pustaka}

Abdusshomad, Muhyiddin. 2014. Fiqh Tradisionalis. Malang: Pustaka Bayan.

Al-Asfihani, Abu al-Qasim al-Husayn bin Muhammad al-Raghib. T.th. Mufradat al-Fadh al-Qur'an Juz II. Damaskus: Daar al-Qolam.

Anshori, Anhar. 2012. Pengantar Ulumul Qur'an. Yogyakarta: Lembaga Pengembangan Studi Islam Universitas Ahmad Dahlan.

Asy-Sya'rawi, Muhammad Mutawalli. 2015. Hadis Qudsi Pilihan. Jakarta: PT Zaytuna Ufuk Abadi.

Baidan, Nashruddin dan Aziz, Erwati. 2016. Metodologi Khusus Penelitian Tafsir. Yogyakarta: Pustaka Pelajar.

Effendy, Onong Uchjana. 2004. Dinamika Komunikasi. PT Remaja Rosdakarya: Bandung.

Hairul, Moh. Azwar. 2019. Tafsir al-Qur'an di Youtobe. Al-Fanar: Jurnal Ilmu al-Qur'an dan Tafsir, 2 (2): 91, 92, 93, 94, 96, 98, 104.

Hamka. 1989. Tafsir al-Azhar Juz IX. Singapura: Pustaka Nasional PTE LTD.

Hamka. 1989. Tafsir al-Azhar Juz. VI. Singapura: Pustaka Nasional PTE LTD.

Hermawan, Acep. 1997. Wawasan al-Qur'an, Tafsir Maudh'i atas Berbagai

Persoalan Umat. Bandung: Mizan.

Hosen, Nadirsyah. 2019. Saring Sebelum Sharing. Yogyakarta: PT Bentang Pustaka.

Hosen, Nadirsyah. 2019. Tafsir al-Qur'an di Medsos. Yogyakarta: Bentang Pustaka.

Ismail, Faisal. 2016. Islam, Doktrin, dan Isu-isu Kontemporer. Yogyakarta: IRCiSoD.

Kafie, Jamaluddin. 1999. Barakah , Apa, Dimana dan bagaimana?, Pasuruan: PT. Garoeda Buana Indah.

Kusroni. 2019. Mengenal Pendekatan, Metode, dan Corak dalam Penafsiran al-Qur'an. Jurnal Kaca Jurusan Ushuluddin STAI Al Fithrah, 1 (9): 89.

Kuswarno, Engkus. dkk., 2010. Komunikasi Kontekstual. Bandung: PT Remaja Rosdakarya.

Mandhur, Abi Fadhal Jamaluddin Muhammad bin Mukarrom Ibnu. T.th. Lisanul Arab Juz. X. Beirut: Daru Shodir.

Muhammad, Ahsin Sakho. 2017. Keberkahan al-Qur'an. Yogyakarta: QAF Media Kreativa.

Mustaqim, Abdul. 2014. Metode Penelitian al-Qur'an dan Tafsir. Yogyakarta: Idea Press Yogyakarta.

Ramli, Muhammad Idrus. 2018. Wahabi Gagal Faham Jilid-1. Pasuruan, Sidogiri Penerbit.

Ramli, Muhammad Idrus. 2018. Wahabi Gagal Faham Jilid-2. Pasuruan, Sidogiri Penerbit.

74 | Muṣhaf: Jurnal Tafsir Berwawasan Keindonesiaan Volume 1. Nomor 1, Desember 2020. 


\section{Lia Qurrota Aini}

Perspektif Barakah Dalam Kesarjanaan Muslim Barat,

Said, Muhammad Sameh. 2002. Muhammad Sang Yatim. Bandung: Cordoba. Sari, Flori Ratna., dkk. 2018. Bekam Sebagai Kedokteran Profetik dalam Tinjauan Hadis, Sejarah dan Kedokteran Berbasis Bukti. Depok: PT RajaGrafindo Persada.

Supiana, M. Karman. 2002. Ulumul Qur'an. Bandung: Pustaka Islamika. Suryanto. 2015. Pengantar Ilmu Komunikasi. Bandung: CV Pustaka Setia.

Tim Penulis. 2018. The 10th Anniversary Edition, the World's 500 Most Influential Muslim 2019. Yordania: Jordan National Library.

bttp:// wnw.nakcollection.com/ naks-biography.btmldiakses 01 Agustus 2019.

https://bincangsyariah.com/khazanah/nouman-ali-khan-tokoh-muslimberpengaruh-asal-pakistan/diakses pada tanggal 06 Mei 2018.

https:/ / katadata.co.id/infografike/2019/03/06/YouTube-medsos-no-1-di-indonesia diakses pada tanggal 06 Maret 2019.

bttps://nakindonesia.com/2017/01/05/biografi-nouman-ali-khan/ diakses 05 Januari 2017.

bttps://threadreaderapp.com/thread/1028673391086120961.html)Thread diakses 2019.

bttps:/ / mww.kompasiana.com/ziaulkausar/5af08a68caf7 db4b1d44c9d3/nouman-alikhan-pakar-tafsir-terkenal-ke-indonesia diakses 08 Mei 2018.

https://www.republika.co.id/berita/koran/newsupdate/16/10/28/ofqog39-membaca-dakwah-nouman-ali-khan diakses pada tanggal 28 Oktober 2016.

https://youtu.be/dHR6i1iK8Tk diakses pada tanggal 17 April 2014. https://youtu.be/dpXbn6LeIIQ diakses pada tanggal 16 Oktober 2013. 